\title{
PENGUATAN FUNGSI PERPUSTAKAAN DAERAH MELALUI PROGRAM STAKE HOALDER MEETING DI PERPUSTAKAAN DAN ARSIP DAERAH KABUPATEN LOMBOK TIMUR
}

\author{
Amin Saleh ${ }^{1}$, Mintasrihardi ${ }^{2}$ \\ Jurusan Ilmu Perpustakaan, Fakultas Ilmu Sosial dan Ilmu Politik \\ Universitas Muhammadiyah Mataram \\ Email: cukum4amin@gmail.com
}

\begin{tabular}{l} 
INFO ARTIKEL \\
\hline Riwayat Artikel: \\
Diterima:...-...-... \\
Disetujui:...-...-... \\
\end{tabular}

Kata Kunci:

Sinergi, stakeholdear meeting, perpustakaan

\section{A. LATAR BELAKANG}

Dinas Perpustakaan dan Kearsipan Lombok Timur melaksanakan peran dan fungsinya pada bidang perpustakaan dengan tugas utama melakukan pengorganisasian atau penyimpanan informasi yang tersetruktur mulai dari pengadaan, pengolahan, pelayanan, perawatan dan promosi.

Komponen kerja perpustakaan tersebut sudah menjadi acuan kerja di setiap perpustakaan sehingga diharapkan pemustakan yang memanfaatkan informasi yang telah disediakan dengan menggunakan sistem yang dapat dipertanggung jawabkan secara professional.

\section{ABSTRAK} hoalder meeting lintas organisasi perangkat daerah di Perpustakaan dan Arsip Daerah Kabupaten Lombok Timur sebagai upaya perpustakaan untuk menguatkan keterlibatan semua kalangan mulai dari aparat pemerintah sampai pada pelibatan masyarakat seihngga perpustakaan menjadi bagian dari tempat berkegiatan semua lapisan masyarakat. Kemudian masalah ditekankan pada kontribusi organisasi pemerintah dan swasta sebagai dampak dari stakeholdear meeting yang di canangkan oleh Dinas Perpustakaan dan Kearsipan Lombok Timur Adapun tujuannya adalah mengetahui kontribusi organisasi perangkat daerah dan pihak swasta dalam mengembangkan fungsi perpustakaan bidang anggaran, program perpustakaan dan pengembangan sumber daya manusia

Adapun metode penelitian dilakukan dengan pendekatan kualitatif deskriptif dengan tekhnik pengumpulan data yang meliputi observasi, wawancara, dan dokumentasi.

Kemudian hasil penelitian menunjukkan organisasi perangkat daerah yang terlibat secara langsung yaitu Dinas PMD, BAPEDA, DISKOMINFO, DISPRINDAG, DAN Dinas Pemberdayaan Wanita dan Keluarga Berencana dengan melakukan penguatan pada bidang anggaran perpustakaan, peraturan derah tentang perpustakaan dan menghadirkan pihak swasta dalam mendukung kegiatan perpustakaan sehingga berdampak pada penguatan jaringan listrik, dan jaringan internet.

\section{$----------\bullet----------$}

Dengan fungsi tersebut perpustakaan menyediakan jasa layanan kepada semua lapisan masyarakat sementara perpustakaan dikatakan sampai pada tujuannya apabila semua lapisan masyarakat telah memanfaatkan kehadirannya.

Perpustakan dengan kekayaan informasi yang dimiliki diharapkan mampu mendukung aktivitas masyarakat menuju terciptanya inovasi dari apa yang telah disediakan di perpustakaan. Artinya perpustakaan akan memfasilitasi masyarakat melalui referensi yang akurat dan sistem yang tepat untuk menghasilkan produktivitas masyarakat yang kompetitif. 
Guna mendukung tercapainya pemenuhan informasi masyarakat yang mampu menjadi referensi dalam setiap aktivitas maka pemerintah memandang penting melakukan pengembangan program perpustakaan berbasis Inklusi sosial yaitu langkah membangun kemandirian masyarakat menuju kualitas yang ideal. Melalui program inklusi sosial, perpustakaan berupaya untuk mendorong elemen masyarakat memperoleh perlakuan yang sama

Upaya perpustakaan untuk menerapkan fungsi dan perannya dihadapan semua lapisan masyarakat maka sangat penting untuk melakukan sinergi lintas organisi perangkat daerah (OPD) untuk duduk bersama dalam memahami makna pembangunan berbasis inklusi sosial yang dituangkan dalam program stakeholder meeting

Stakeholder adalah individu, komunitas maupun lembaga baik swasta maupun pemerintah yang memiliki tanggungjawab dan komitmen dalam pengembangan perpustakaan sehigga Pertemuan Stakeholder / Stakeholder Meeting adalah kegiatan mempertemukan para pemangku kepentingan untuk mendukung transformasi perpustakaan di kabupaten lombok timur tentunya dengan menyadari bahwa organisasi perangkat daerah (OPD) yang menjadi bagian penyelenggara pemerintahan di kabupaten lombok timur memiliki peran yang sangat strategis untuk mendukung program perpustakaan dalam mencerdaskan kehidupan bangsa

Kegiatan utama yang langusung dirasakan oleh perpustakaan dalam keberadaan perpustakaan dapat dipastikan dari sudut pelayanan untuk memenuhi kebutuhan pemustaka. Pada pelayanan inilah berlangsung hubungan dan harapan antara pengelola perpustakaan dan pemustaka sebagai target perpustakaan. Pelayanan yang diharapkan baik oleh penyedia layanan maupun pemustakaan sebagai penerima layanan, tentunya adalah pelayanan yang terbaik (pelayanan perima) sementara baik dan tidaknya pelayanan perpustakaan bergantung pada kesiapan dan tekhnis pelayanannya.
Adapun dalam binaan itu yang diperioritaskan adalah kemampuan untuk melakukan advokasi bagi para stakhodear perpustakaan, pengelolaan perpustakaan desa, pelaporan online dan kemampuan untuk melakukan pelibatan masyarakat.

1. Masalah

Mengacu pada paparan latarbelakang yang telah diuraikan sebelumnya maka yang menjadi focus malaha disini adalah:

a. Bagaimana kontribusi organisasi perangkat daerah melalui stakeholdear meeting di perpustakaan kabupaten lombok timur

b. Bagaimana kontribusi perusahaan swasta dalam mendukung program perpustakaan melalui stakehoaldear meeting

\section{Tujuan Penelitian}

Proses penelitian yang akan dilakukan diharapkan mampu untuk mengurai menghantarkan pada pola pengelolaan perpustakaan yang mencerdaskan kehidupan bangsa dan negara. Untuk itu tujuan penelitian ini adalah :

a. Untuk mengetahui Kontribusi Organisasi Pemerintah Daerah pada stakeholdear meeting

b. Untuk mengetahui kontribusi pihak Suwasta dalam stakeholdear Meeting

\section{B. LANDASAN TEORI}

1. Perpustakaan

Menurut Undang-Undang Nomor 43 tahun 2007 perpustakaan adalah "institusi pengelolah koleksi karya tulis, karya cetak, dan/atau karya rekam secara professional dengan sistem yang baku guna memenuhi kebutuhan pendidikan, penelitian, pelestarian, informasi, dan rekreasi para pemustaka.

Sementara perpustakaan desa/kelurahan menurut standar nasional perpustakaan yang dikeluarkan oleh perpustakaan nasional tahun 2013 adalah perpustakaan yang diselenggarakan oleh pemerintah desa/kelurahan yang mempunyai tugas pokok melaksanakan pengembangan 
perpustakaan di wilayah desa/kelurahan serta melaksanakan layanan perpustakaan kepada masyarakat umum yang tidak membedakan usia, agama, status sosialekonomi dan gender. Sementara menurut Rachman Hermawan dan Zulfikar Zen (2006:30) perpustakaan umum adalah perpustakaan yang melayani seluruh lapisan masyarakaat tanpa membedakan latar belakang, status sosial, agama, suku, pendidikan, dan sebagainya.

Sehingga layanan perpustakaan menurut Menurut Darmono (2001 : 134), bahwa layanan perpustakaan adalah suatu layanan yang menawarkan semua bentuk koleksi yang dimiliki perpustakaan kepada pemustaka yang datang ke perpustakaan dan meminta informasi yang dibutuhkan.

Dengan demikian maka layanan perpustakaan secara inti adalah untuk memberikan layanan berupa informasi yang dapat memenuhi kebutuhan informasi masyarakat. Sehingga dalam kegiatan ini yang melekat pada layanan perpustakaan adalah perpustakaan melaksanakan kegiatan untuk mampu memberikan pelayanan tentunya dengan standar kerja yang profesional dan berkesinambungan seperti aktif dalam melakukan pengadaan sumber informasi, pengecekan informasi, pengeolahan informasi, dan perawatan informasi

Mengingat latar belakang dan ragam kebutuhan informasi yang diharapkan masyarakat maka langkah kerja yang profesinal harus ditempuh supaya tujuan umum dari keberadaan perpustakaan di desa dapat terlaksana dengan baik dan dirasakan dampak positifnya oleh masyarakat dalam hal keterpenuhan kebutuhan pada informasi dan setelah itu masyarakat akan merasa terbantukan baik dalam hal mendukung proses kerja yang digeluti maupun mencari potensi yang harus dikembangkan.

\section{Stakeholder Meeting}

Menurut undang-undang no 43 tahun 2007 yang mengatur tentang perpustakaan pada BAB I menyatakan perpustakaan adalah institusi yang mengumpulkan pengetahuan tercetak dan terekam, mengelolanya dengan cara khusus guna memenuhi kebutuhan intelektualitas para penggunanya melalui beragam cara intraksi pengetahuan. Dengan demikian perpustakaan adalah fasilitas atau tempat mnyediakan sarana bahan bacaan. Tujuan dari perpustakaan sendiri, adalah memberikan layanan informasi untuk kegiatan belajar, penelitian, dan pengabdian masyarakat.

Perpustakaan menjadi jenis lembaga atau institusi yang diharapkan mampu mengakomodir setiap kebutuhan yang datang dari berbagai lapisan masyarakat mulai dari kalangan elit sampai pada masyarakat pedesaan. Berdasarkan hal tersebut maka stakeholder meeting di pandang langkah yang sangat strategis untuk mewadahi advokasi yang ditujukan kepada lintas organisasi pemerintah (OPD) terkait.

Stakeholder adalah individu, komunitas maupun lembaga baik swasta maupun pemerintah yang memiliki tanggungjawab dan komitmen dalam pengembangan perpustakaan sehigga Pertemuan Stakeholder / Stakeholder Meeting adalah kegiatan mempertemukan para pemangku kepentingan untuk mendukung transformasi perpustakaan di kabupaten lombok timur tentunya dengan menyadari bahwa organisasi perangkat daerah (OPD) yang menjadi bagian penyelenggara pemerintahan di kabupaten lombok timur memiliki peran yang sangat strategis untuk mendukung program perpustakaan dalam mencerdaskan kehidupan bangsa

\section{METODE PENELITIAN}

Penelitian tentang penguatan perpustakaan melalui stakehoaldear meeting dilakukan dengan pendekatan kualitatif deskriptif dengan maksud menarasikan data yang diperoleh.

Menurut Moleong, (2002: 3) Penelitian kualitatif adalah prosedur penelitian yang 
menggunakan data deskriptif berupa kata-kata tertulis atau lisan dari orang- orang dan perilaku yang diamati yaitu tentang upaya pengembangan fungsi perpustakaan kabupaten lombok timur melalui pemberdayaan organisasi perangkat

1. Pengumpulan Data

Pengumpulan data penelitian dilakukan dengan melakukan pengamatan (observasi) yaitu melihat secara langsung kejadian-kejadian atau tindakan-tindakan yang dilakukan oleh informan. Kedua peneliti melakukan wawancara (interview) secara terbuka dengan mengunakan pedoman wawancara yang telah disusun sebelumnya, tetapi dikembangkan pada saat wawancara. Ketiga dengan melakukan pendokumentasian (dokumentasi) untuk menguatkan dokumen sebagai bukti dari adanya suatu penelitian di daerah yang diteliti.

2. Teknik Analisa Data

Analisis data dimulai dengan memahami seluruh data yang diperoleh dari hasil wawancara dengan informan, yang kemudian direduksi dengan cara membuang kata-kata yang dianggap tidak perlu untuk mendapatkan inti atau pokok kalimat dari jawaban

Pertanyaan-pertanyaan yang diajukan kepada informan. Kemudian data tersebut disusun dalam bentuk satuan-satuan yang kemudian dikelompokkan berdasarkan kategori tertentu.

Tahapan berikutnya adalah melakukan penyajian data. Dalam penelitian kualitatif penyajian data dapat dilakukan dalam bentuk uraian singkat, bagan, hubungan antar kategori, flowchart dan sejenisnya.

Tahap akhir proses pengumpulan data adalah verifikasi dan penarikan kesimpulan yang dimaknai sebagai arti data yang telah ditampilkan.

3. Waktu Penelitiaan

Penelitian dilakukan dalam waktu kurang lebih 5 bulan mulai Maret 2019 s/d Agustus 2019. Selanjutnya secara lebih lengkap mengikuti peraturan lembaga penelitian dan pengabdian masyarakat (LPPM) Universitas Muhammadiyah Mataram.

\section{PEMBAHASAN}

Penelitian tentang pelibatan organisasi perangkat daerah (OPD) yang di lakukan dinas perpustakaan dan kearsipan kabupaten lombok timur dilakukan atas dasar pentingnya kepedulian bersama dalam mewujudkan perpustakaan untuk masyarakat. Sehingga perpustakaan melakukan stakeholder meeting dengan mengundang organisasi perangkat daerah lainnya yang di tetapkann dalam program perpustakaan selama satu kali dalam satu tahun. Stake holdear meeting dilakukan oleh dinas perpustakaan dan kearsipan kabupaten lombok timur dengan mengundang organissi yang dianggap mampu memberikan kontribusi dalam mengadvokasi masyarakat untuk melibatkan perpustakaan sebagai media belajar sepanjang waktu.

a. Kontribusi organisasi perangkat daerah melalui stakeholdear meeting.

Kehadiran perpustakaan menjadi bagian penting yang akan mengisi catatan menuju fakta dan data yang sesuai menurut zaman yang di lalui. Sehingga sesuai dengan visi darii perpustakaan yaitu untuk mewujudkan tertib adminstrasi pelayanan perpustakaan dan kearsipan yang dinamis dan informatif dalam penyelenggaraan pemerintahan, pembangunan dan kemasyarakatan.

Hadirnya perpustakaan menjadi harapan pemerintah kabupaten lombok timur untuk mewujudkan terlaksananya pemerintahan yang mampu memberikan gambaran terwujudnya dinamika pemerintahan yang mapu membawa masyarakat pada terlaksananya sistem kehidupan yang aman, nyaman, kreatif, dan inovatif.

Perpustakaan kabupaten lombok timur sekaligus akan berfungsi sebagai bukti capaian masyarakat sekaligus pemerintah yang ditandai dengan terlaksanya pembangunan yang berorientasikan pada jangka pendek, jangka menengah dan jangka panjang. Tentunya dengan 
menyentuh setiap aspek diantaranya, ekonomi, kesehatan, pendidikan dan aspek-aspek penting lainnya.

Keadaan inilah yang akan menjadi penuntun untuk menjadikan masyarakat sebagai penerima manfaat dari setiap kebijakan pemerintah secara khusus kehadiran perpustakaan yang diperkuat oleh kebijakan-kebijakan yang akan memberikan dampak baik secara langsung maupun tidak langsung pada setiap lapisan masyarakat.

Keinginan pemerintah untuk menghadirkan perpustakaan yang representatif sudah menjadi tanggung jawab yang amat penting mengingat secara umum indonesia adalah negara yang sedang membangun sehingga setiap kebutuhan masyarakat akan di tumpukan pada kebijakan pemerintah.sementara itu, Semangat untuk menghadirkan sejarah pemerintah yang baik dan berkemajuan menjadi tanggung jawab perpustakaan, untuk itu perpustakaan melakukan trobosan dengan melibatkan organisasi perangkat daerah lainnya, seperti

\begin{tabular}{|c|c|}
\hline No & Instansi \\
\hline 1 & $\begin{array}{c}\text { Dinas Pemberdayaan } \\
\text { masyarakat Desa }\end{array}$ \\
\hline 2 & Dinas Perdagangan \\
\hline 3 & Dinas Koprasi dan UMKM \\
\hline 4 & Badan Perencanaa Daerah \\
\hline 5 & $\begin{array}{c}\text { Dinas komunikasi dan } \\
\text { Informasi }\end{array}$ \\
\hline 6 & $\begin{array}{c}\text { Dinas Pemberdayaan } \\
\text { Perempuan dan Keluarga } \\
\text { berencana }\end{array}$ \\
\hline
\end{tabular}

Stake holdear meeting diprogramkan oleh dinaas perpustakaan dan kearsipan kabupaten lombok timur satu kali dalam setahun menurut Kepala Dinas Perpustakaan dan Kearsipan saat ditemui (14/05/19), program ini diharapkan memberi dampak yang efektif pada kegiatan advokasi yang secara tidak langsung akan mempengaruhi persepsi masyarakat secara lebih luas. Stakeholdear meeting dilakukan secara formal yaitu dengan cara perpustakaan melakukan identifikasi perangkat pemerintah yang memiliki keterkaitan langsung dengan masyarkat, baru setelah itu perpustakaan membuat surat undangan resmi dengan mengharapkan kehadiran kepala dinas atau kepala bidang yang dianggap memiliki pengaruh besar di dalam organisasinya secara husus dan masyarakat secara lebih luas.

Kehadiran dinas dimaksudkan dapat memberikan kontribusi khususnya pada bidang anggaran perpustakaan, program perpustakaan dan sumberdaya manusia perpustakaan yang telah dilakukan di dinas perpustakaan dan kearsipan kabupaten lombok timur:

a. Anggaran perpustakaan

Sejak awal tahun 2018 status Kantor berubah menjadi Dinas dengan terbitnya Peraturan Daerah Kabupaten Lombok Timur Nomor o6 Tahun 2016 tentang Pembentukan dan Susunan Perangkat Daerah dan Peraturan Bupati Lombok Timur Nomor 52 Tahun 2016 tentang Kedudukan, Susunan Organisasi, Uraian Tugas, Fungsi dan Tata Kerja Dinas Perpustakaan dan Kearsipan. Dengan uraian 3 bidang yaitu Bidang Perpustakaan, Kearsipan, Pembinan dan Pengembangan serta 2 Kasubbag yaitu Kasubag Keuangan dan Program serta Kasubag Umum Kepegawaian.

b. Dinas PMD

Penguatan dalam bentuk regulasi seperti pengajuan draf peraturan bupati tentang penggunaan dana desa sebagai sumber anggaran pengelolaan perpustakaan yang dimuat dalam peraturan bupati lombok timur nomor 6 tahun 2019 tentang pedoman penyusunan anggaran pendapatan dan belanja desa tahun anggaran 2019 pada psal 11 huruf a bdang pendidikan pada bidang ke delapan (8) yang menyatakan pengelolaan perpustakaan milik desa (pengadaan buku bacaan, honor penjaga untuk perpustakaan/taman baca desa.

Memasukkan program perpustakaan dalam aplikasi Siskiudes.Kehadiran Dinas 
Pemberdayaan Masyarakat Desa mejnadi sangat penting untuk mengadvokasi setiap desa/kelurahan yang ada untuk memasukkan komponen pembiayaan program perpustakaan melalui aplikasi SisKiuDes mulai dari penganggaran dalam melakukan pengadaan, pengolahan, pelayanan, perawatan dan promosi perpustakaan, hingga pemberihan honor bagi petugas pelaksana yang di tunjuk untuk melaksnakan fungsi perpustakaan secara profesional. Adanya penguatan pada tersedianya ruang/komponen di SisKiuDes akan memudahkan bagi kepala desa dan perangkat desa lainnya untuk memahami pentingnya memperhatikan perpustakaan dalam pembangunan di tingkat masyarakat.

Sosialisasi pembentukan perpustakaan desa Dinas Pemberdayaan Masyarakat desa bersama Dinas Perpustakaan kabupaten lombok timur telah bersama-sama melakukan sosialisasi pembentukan perpustakaan desa di masing-masing desa/kelurahan. Sampai dengan saat ini sudah 36 desa menjadi sasaran sosialisasi yang diharapkan mampu menjadi sampel penggerak bagi semua kepala desa untuk memperhatikan program perpustakaan yang hadir sebagai program pengembangan sumberdaya masyarakat desa.

Menurut Andre saat di temui 17/05/19 (koordinator bidang replikasi perpustakaan desa/kelurahan) menyatakan dengan adanya komitmen Dinas Pemberdayaan Masyarakat Desa menjadi kemudahan tersendiri bagi Dinas perpustakaan dalam rangka menyentuh perhatian kepala desa dan masyarakat sekitar. Sehingga program perpustakaan dapat dengan mudah diperhatikan dan di terapkan sebagai langkah kebijakan yang akan mapu memberikan kontribusi nyata bagi terwujudnya masyarakat yang aktif, kreatif, dan agresip menuju masyarakat yang kompetitif.

\section{c.BAPEDA}

Hadirnya badan perencanaan daerah kabupaten lombok timur akan memberikan dampak pada Regulasi perencanaan pengebangan perpustakaan desa percontohan dengan memberikan bantuan lewat pemerintah daerah dan Membuat pagu anggaran untuk perpustakaan desa

\section{d. DISKOMINFO}

Keberadaan Dinas Komunikasi dan informasi dengan visi Membangun dan Meningkatkan Infrastruktur Wilayah secara berimbang pada Bidang Transportasi, Energi, Irigasi, Air Bersih serta Perumahan. Dengan demikian maka kontibusi secara langsung pada perpustakaan meliputi:

1. Melayani pengaduan pelayanan publik dalam hal pemanfaatan jasa perpustakaan sehingga perpustakaan membuka akses layanan secara profesional

2. Jaringan internet yang digunakan di dinas perpustakaan daerah maupun perpustakaan desa/kelurahan yang menjadi perpanjangan fungsi perpustakaan daerah kabupaten

3. Dinas Pemberdayaan Perempuan dan Keluarga Berencana hadir untuk turut serta endukung terlaksananya program perpustakaan sehingga membantu dalam mensosialisasikan dengan cara pelibatan PKK dan karangtaruna desa

\section{e.Program perpustakaan}

Dinas perpustakaan dan kersipan kabupaten lombok timur lewat sinergi dan pelibatan organisasi perangkat daerah lainnya dalam merumuskan program kerja perpustakaan yang menargetkan masyarakat sebagai sasaran utama yang diharapkan mampu memberian dampak pada peningkatan penghasilan masyarakat, pendidikan, kesehatan dan lain-lannya. 
Program unggulan perpustakaandaerah kabupaten lombok timur mulai tahun 2013 s/d 2019 yaitu melakukan replikasi terhadap desadesa yang berkomitmen melaksanakan jasa layanan perpustakaan desa. Sampai tahu ini sudah 29 desa yang telah di replikasi.

\section{f. Sumber daya manusia}

Dinas Perpustakaan dan Kearsipan Kabupaten Lombok Timur memberikan pelatihan tentang tata kelola perpustakaan desa/kelurahan. Kegiatan ini diikuti para Pengelola Perpustakaan Desa/Kelurahan yang bertujuan untuk menambah wawasan dan pengetahuan serta meningkatkan kualitas sumber daya manusia dalam upaya memajukan perpustakaan desa/kelurahan di Lombok Timur.

Sekdis Perpustakaan dan Kearsipan Lotim Drs. H. Hamdillah dalam sambu-tannya mengharapkan kepada para pengelola perpustakaan agar mampu menjadi motivator untuk meningkatkan minat baca masyarakat.

Kabid Pembinaan dan Pengembangan Perpustakaan Lalu Nadi Abidin Ali mengatakan, sumber daya manusia di perpustakaan merupakan salah satu faktor penting untuk perkembangan dan kemajuan perpustakaan, sumber daya manusia juga menjadi asset yang sangat penting dalam suatu organisasi. Oleh karena itu, asset tersebut harus dikembangkan guna memenuhi kebutuhan dalam perkembangan perpustakaan.

Dalam pelatihan dan pembinaan ini, ujarnya, yang menjadi sasarannya adalah Pengelola Perpustakaan Desa/Kelurahan yang ada di Lombok Timur dengan jumlah peserta sebanyak 30 orang, kegiatan ini berlangsung 3 hari (tgl 21-23/3/19) yang dipusatkan di aula Kantor Dinas Perpustakaan dan Kearsipan Lotim.

\section{g. Kontribusi pihak swasta}

Perpustakaan daerah kabupaten lombok timur menyadari sepenuhya bahwa dalam melaksanakan tugas sangat penting untuk melibatkan pihak swasta. Untuk itu perpustakaan juga mengundang pihak swasta dalam acara Stake Holdear Meeting. Adapun yang hadir dan berkomitmen diantaranya PT. Telkom dan PT. PLN dengan memberi dukungan pada penguatan jaringan listrik dan jaringan internet terutama di perpustakaan desa binaan perpustakaan dan kearsipan kabupaten lombok timur.

\section{E. KESIMPULAN}

Kontribusi dari keterlibatan organisasi perangkat daerah (Dinas PMD, BAPEDA, DISKOMINFO, DISPRINDAG, Dinas Pemberdayaan wanita dan Dinas Koprasi dan UKM) yang dirasakan langsung oleh perpustakaan daerah dan perpustakan desa mulai dari program perpustakaan tidak lagi kaku pada konteks buku dan bacaan, anggaran perpustakaan, dan penguatan sumber daya manusia.

Kontribusi pihak swasta (PLN dan PT. Telkom) dalam mensukseskan program perpustakaan bertindak sebagai Library Supforter dengan memberikan bantuan seperti jaringan internet, penguatan jaringan listrik. 


\section{DAFTAR PUSTAKA}

Basuki, Sulistyo, 1991. Pengantar Ilmu Perpustakaan, Jakarta: Gramedia.

Darmono.2001. Manajemen Perpustakaan. Jakarta: Grasindo.

Daryono.2010. Kompetensi Pustakawan Dalam Memberikan layanan Prima di Perpustakaan Perguruan Tinggi. Jurnal Kepustakawanan dan Masyarakat

Hermawan, Rachman dan Zulfikar Zen. 2006. Etika kepustakawanan, Jakarta: Agung Seto.

Idrus, Muhammad.2009. Metode Ppenelitian ilmu sosial pendekatan kualitatif dan Kuantitatif, Jakarta: Airlangga.

Indonesia Depdikbud, 1995. Kamus besar bahasa indonesia. Jakarta: Balai pustaka.

Indonesia. 2007. Undang-Undang RI Nomor 43 tentang perpustakaan. Jakarta: Harvarindo.

Moleong, lexyi. 2002. Metodologi penelitian kualitatif. Bandung: PT. Remaja Rosdakarya.

Masruri, Anis. Kualitas pelayanan perpustakaan (Studi kasus pada perpustakaan IAIN

Sunan kalijaga yogyakarta). Jurnal berkala ilmu perpustakaan dan informasi No.II, Nomor 2, 2004. Yogyakarta: Universitas Gadjah Mada.

Nawawi, Hadari dan Martini Hadari. 1995 Instrumen Penelitian Bidang Sosial. Yogyakarta: UGM Press.

Patilima Hamid. 2011. Metode Penilitian Kualitatif. Bandung: CV Alvabeta.

Pamuntjak, Rusina Syahrial, 200o. Pedoman Penyelenggaraan Perpustakaan, Jakarta: Pustaka Jaya.

Soeathmina, 1992. Perpustakaan, Kepustakawanan dan Pustakawan. Yogyakarta: Kanisius.

Sutarno, N.S., 2004. Manajemen Perpustakaan Suatu pendekatan, Jakarta: Samitra Media Utama.

Yusuf, Pawit M. 1995. Pedoman praktis mencari informasi. Bandung : Remaja Rosda Karya. 